\title{
OBLIKOVANJE ČEZMEJNIH VEZI NA TROMEJI MED SLOVENIJO, HRVAŠKO IN ITALIJO V ISTRI
}

\begin{abstract}
Milan Bufon*
\section{Izvleček}

Prispevek obravna nekatere vidike obmejnosti in razvoja čezmejnega povezovanja na stromeji« med Slovenijo, Italijo in Hrvaško $v$ Istri. Uvodoma so predstavljeni nekateri geopolitični vidiki formiranja in preoblikovanja obravnavanega obmejnega in družbeno-kulturnega kontaktnega območja. $V$ nadaljevanju so prikazani nekateri rezultati raziskovalnega projekta, ki se bo zaključil v letu 2001 in bo to območje tudi primerjal z ostalimi slovenskimi obmejnimi območji, za katera se že zbirajo ustrezne informacije. Na osnovi metodologije, ki jo je avtor prispevka razvil $\checkmark$ domačem in mednarodnem znanstvenem okolju, so $v$ prispevku prikazani tipologija, intenzivnost in smer čezmejnih vezi $v$ različnih delih, ki sestavljajo obravnavano »tromejo«. Prispevek zaključuje krajša primerjalna analiza istrske »tromeje« z drugimi obmejnimi območji vzdolž slovensko-italijanske meje.
\end{abstract}

Ključne besede: Istra, oblikovanje obmejnega območja, čezmejne vezi med Slovenijo, Hrvaško in Italijo

\section{DEVELOPMENT OF CROSS-BORDER RELATIONS IN THE ISTRIAN THREE-BORDER AREA BETWEEN SLOVENIA, CROATIA, AND ITALY}

\begin{abstract}
The paper exames some aspects of 'borderness' and development of cross-border relations in the three-border area between Slovenia, Croatia, and Italy in Istria. Firstly, some geopolitical aspects of forming and transformation of the considered border and social-cultural contact area are given. The paper than presents some results of a research project, which will be concluded in 2001 comparing the
\end{abstract}

"Dr., doc., Oddelek za geografijo, Filozofska fakulteta, Aškerčeva 2, 1000 Liubljana, Slovenija 
studied region with other Slovenian border areas. On the basis of the author's methodology, which has been developed in the domestic and international scientific community, typology, intensity and direction of cross-border relations in different parts of the Istrian 'three-border' are then discussed. The paper concludes with a short compared analysis of the studied border region with other studied border landscapes along the Italo-Slovene border.

Key words: Istria, development of the border status, cross-border relations between Slovenia, Croatia, and Italy

\section{Geopolitične osnove oblikovanja istrske »tromeje» med Slovenijo, Hrvaško in Italijo}

Politično geografijo Istre je $v$ bistvu krojilo razmerje med etnično in politično mejo, obe pa lahko potekata bodisi pravokotno ali vzporedno druga z drugo in s tem oblikujeta to, kar bi lahko imenovali istrski »križ巛 (Bufon, 1993). Začetke »modernih« političnih meja v obravnavanem območju gre iskati v času med 13. in 15. stoletjem, ko je Beneška republika utrdila svojo istrsko posest. Končno podobo je meja med Beneško republiko in habsburško državo dobila ob podpisu mirovne pogodbe leta 1521 in se ni več spremenila do konca 18. stoletja. Na ta način se je nekako oblikovala navpična, tradicionalno politična os istrskega »križa«, ki pa je $v$ resnici vse prej kot premočrtna, saj poteka v smeri narobe obrnjene črke "S«. Pravilnejši potek kaže historična etnična meja italijanskega prebivalstva, ki obsega zahodni obalni del Istre skorajda $v$ ravni črti med Koprom in Pulo. Približno v istem času kot politična beneško-avstrijska meja, se pravi med 12. in 15. stoletjem, se je oblikovala tudi vodoravna os tega zanimivega istrskega »križa«, in sicer etnična meja med slovenskim in hrvaškim prebivalstvom, ki pa do danes ni imela nobene politične funkcije. Slovenska naselitev $v$ območju se je tedaj ustavila ob Dragonji ter na črti severno od Buzeta in Rupe ter se $v$ bistvu kasneje ni več spremenila, kar je precej nenavadno, saj, kot rečeno, to etnično mejo $v$ tem sektorju ni nikoli podprla ustrezna politična delitev. Sicer pa niti navpična romansko-slovanska niti vodoravna slovensko-hrvaška etnična meja nista nikoli predstavliali pravo jezikovno pregrado med istrskim prebivalstvom, saj so 
vsi trije jeziki in odgovarjajoča narečja prehajali drug $v$ drugega in se ne le $v$ mestih, ampak tudi na podeželju med seboj močno prepletali.

Funkcija stare beneško-avstrijske meje je dejansko prenehala šele po koncu Ilirskih provinc, ko je celoten polotok postal enotna administrativna enota $\mathrm{s}$ sedežem $v$ Pazinu, medtem ko se je $v$ upravnem pogledu avstrijska dežela Istra oblikovala šele leta 1861, ko je dobila deželni zbor s sedežem v Poreču, medtem ko sta bila glavarstvo in magistrat $v$ Rovinju. Tudi po prvi svetovni vojni, ko je to območje zasedla Italija, je večji del Istre ohranil upravno samostojnost, čeprav tokrat kot italijanska provinca s sedežem v Puli. Po drugi svetovni vojni so bili opravlieni nekateri poskusi revitalizacije navpične osi istrskega »križa«, za katero se je posebno zavzemala italijanska stran. Kot delni rezultat teh prizadevani lahko štejemo t.i. Morganovo linijo, ki je od leta 1945 do zaključka mirovnih konferenc leta 1947 razdeljevala angloameriško od jugoslovanske okupacijske cone znotraj spornega ozemlja med staro avstrijsko-italijansko in po prvi vojni nastalo italijansko-jugoslovansko mejo. Dejansko njen potek ni ostal brez vpliva na kasnejše razmejitvene predloge, zlasti na sprejeti francoski predlog, ki je temeljil na načelu t.i. etničnega ravnovesja in predvideval ustanovitev vmesne, $v$ bistvu spet začasne teritorialne enote, to je Svobodnega tržaškega ozemlja. Že leta 1954 je bilo tudi to ozemlje razdeljeno med obe strani in s tem je bila dokončno odpravljena vertikalna os istrskega »križa", polotok pa je bil skoraj v celoti priključen $k$ Jugoslaviji. Znotraj te države je slovensko-hrvaška etnična meja prvič pridobila status administrativne meje med republikama, z letom 1991 pa tudi državne meje.

Vse te razmejitvene spremembe, do katerih je prišlo zlasti v zadnjem stoletju po dolgotrajnem obdobju politične stabilnosti, so seveda močno vplivale na podobo Istre, še posebno na njeno etnično strukturo in širše prostorske vezi. Predvsem je bil iz polotoka zaradi različnih motivov skoraj povsem izrinjen nekdaj dominanten romanski element. Po avstrijskem popisu iz leta 1910 je tu (brez Trsta in Rijeke) živelo okrog 135 tisoč Italijanov, okrog 105 tisoč Hrvatov in okrog 25 tisoč Slovencev, kar pomeni, da se je v prvem povojnem obdobju iz tistega dela Istre, ki je prešel k Jugoslaviji, izselilo približno 100 tisoč avtohtonih Istranov romanske kulture in jezika, katerim se je pridružilo še kakih 50 tisoč izseljencev iz Rijeke, Kvarnera in Dalmacije. Dobršen del tega prebivalstva (okrog 65 tisoč) so italijanske oblasti naselile $\vee$ Tržaški pokrajini, preostalih 85 tisoč pa je nadaljevalo pot $v$ druge kraje Italije. Ta pojav je imel 
nato različne posledice $v$ meddržavnih, medetničnih in regionalnih razmerah $v$ Zgornjem Jadranu (Bufon, 1997). Če se omejimo le na istrski prostor, bi lahko rekli, da to, kar je bila nekdaj boli ali mani razpoznavna etnična meja, je danes le nekakšen okvir kulturnega prostora, ki je izgubil večji del svojih glavnih nosilcev, a ohranja svoi pomen $v$ pogledu regionalne identitete istrskega prebivalstva in vpliva celo na osebe, ki so se sem naselile od drugod. Poleg tega se je z emigracijo avtohtonega prebivalstva ta identiteta prostorsko močno razširila in vpliva na oblike prostorske povezanosti $v$ širšem regionalnem okolju. Še posebno so se na ta način okrepile vezi med Trstom in Istro: te vezi so $v$ preteklosti slonele na pragmatičnih ekonomskih temeljih, a so po prihodu istrskih izseljencev $v$ mesto zadobile zelo intenzivne emotivne dimenzije, ki temeljiio na dejstvu, da je $v$ Trstu in njegovi okolici koncentrirana večina italijanskega oziroma italijansko opredeljenega prebivalstva Istre, ki ostaja še nadalje tesno navezano na lastno izvorno ozemlje in s tem vpliva na marsikatero določitev italijanskih centralnih in lokalnih oblasti. V tej luči postaja Trst, kljub dvojni meji, ki ga ločuje od glavnine svojega istrskega zaledja, novi "Caput Istriae« in prevzema tako funkcijo, ki jo pred tem ni imel, saj je bil do druge polovice 19. stoletja veliko bolj »kontinentalno« orientiran. Po drugi strani pa ni ne na slovenski ne na hrvaški strani enako stežkega» jedra, ki bi uspel to regijo povezati. Še celo na mezoregionalni ravni prihaja do delitve vpliva, v hrvaškem delu zlasti med »kontinentalnim« Pazinom na eni strani in serijo obalnih mest (s Porečom, Rovinjem in Pulo na čelu) na drugi, $\checkmark$ precei manjšem slovenskem delu Istre pa celo med vsemi tremi obalnimi mesti, čeprav se tu Koper vendarle uveljavlja kot prevladujoče središče.

$\checkmark$ nekem smislu je vprašanje istrskega regionalnega središča tudi vprašanje različnih geopolitičnih in politično geografskih interpretacii istrskega prostora. Za časa Avstrije je bila ta funkcija najprej dodeljena »kontinentalnemu« Pazinu, pod pritiskom italijanske komponente in obalnih lokalnih oblasti pa je bil nato vpeljan nekakšen regionalni dualizem med Porečom in Rovinjem. Italijanski maritimni koncept je prišel jasno do izraza po prvi svetovni vojni, ko je bila funkcija pokrajinskega sedeža dodeljena Puli, medtem ko se je po letu 1991 hrvaška oblast odločila za to, da bi bil sedež istrske županije spet v Pazinu, kar očitno ustreza obnovljenemu kontinentalnemu konceptu istrske regije. Toda kakorkoli stvari obračamo, ne moremo mimo dejstva, da ostaja Istra relativno homogeno historično in kulturno območje. To območje si sedaj delijo tri samostojne države, in čeprav je njihov istrski »deležu v demografskem in 
teritorialnem pogledu zelo različen in tudi protisloven, pa je tudi res, da so $\mathrm{v}$ vseh treh enotah prisotni prav vsi elementi istrske identitete. Zaradi tega svojega položaja je Istra $\vee$ Evropi poseben primer obmejne regije, ki bo nedvomno še zaposloval številne raziskovalce njenih družbenih in prostorskih problemov in ki prav gotovo zasluži ustrezen posluh in pristop s strani zainteresiranih držav, da bi to območje ostalo, ali bolje postalo območje dejanske in na enakopravnih odnosih grajene mednarodne in medetnične integracije in sodelovanja.

\section{Čezmejne vezi v istrski »tromeji»}

\section{Osnovne prostorske vezi}

$\checkmark$ nadaljevanju bodo prikazani prvi rezultati terenske raziskave, ki je na osnovi metodologije, ki jo je avtor tega prispevka razvil na primeru goriškega obmejnega območja, tokrat zajela nad 750 gospodinjstev na območju Slovenske Istre ter $v$ sosednjih obmejnih krajih $v$ Italiji in na Hrvaškem. Anketiranje v izbranih območjih te zanimive "tromeje" je želelo ugotoviti spremembe, predvsem pa sedanje stanje glede usmerjenosti in intenzitete čezmejnih odnosov, kakor tudi vrednotenja obmejnosti in sosedov v tem verjetno najbolj reprezentativnem slovenskem obmejnem območju, ki je med vsemi tudi najbolj urbanizirano in izrazito regionalno opredelieno. Sicer pa bo predvidoma do konca leta 2001 enotno obdelan celoten slovenski obmejni pas in bo tako mogoče različne obmejne dele tudi medseboi primerjati in jih rangirati oziroma tipizirati po stopnii kvalitete in intenzitete čezmejnih odnosov ter hkrati ugotoviti faktorje za razlike $v$ pojavnih oblikah obmejnosti oziroma obstoj večje ali manjše predispozicije obmejnega prebivalstva do čezmejnega sodelovanja.

Skupno je bilo na območju istrske "tromeje" 51 \% anket opravljenih v Sloveniii, 38 \% na Hrvaškem in 11 \%v Italiii, kar nekako odgovarja distribuciji prebivalstva znotraj obravnavanega obmejnega prostora. Od tega je bilo $v$ italijansko-slovenskem obmejnem pasu narejenih 22,5 \% anket, $v$ hrvaškoslovenskem obmejnem pasu pa $48 \%$ vseh anket. Preostalih približno $30 \%$ anket, ki so bile opravljene izven ožjega obmejnega pasu, je nudilo kontrolne vrednosti, s katerimi smo lahko primerjali pridobliene rezultate $v$ obmejnih conah in $s$ tem testirali efekt meje oziroma bivanja $v$ njegovi bližini na 
vrednotenje obmejnosti in samo vedenje prebivalstva $v$ odnosu do sosednjih območii.

Analiza prostorske mobilnosti obmejnega prebivalstva je pokazala, da so $v$ vseh območjih, razen $v$ urbanem delu Slovenske Istre, kjer $v$ tem pogledu izstopajo starši intervjuvanih, najboli mobilna "kategorija" prebivalstva "zakonci". V tistem delu italijanskega obmejnega območja, ki je pretežno poseljen s Slovenci, je mobilnost zakoncev celo več kot dvakrat višja kot pri ostalih družinskih članih. Skupno znaša pri intervjuvanih delež rojenih v območju bivanja 58\%, kar kaže na to, da je obravnavano istrsko območje doživelo precejšnje prostorske in demografske spremembe. $\mathrm{V}$ ožjem slovenskem, hrvaškem in italijanskem obmejnem pasu znaša ta delež $66 \%$, v ostalih, "notranjih" območjih pa celo komaj 37\%. Da je glavno "žarišče" demografskih transformacij notranja Slovenska Istra, razberemo iz podatka, da znaša delež rojenih $\vee$ območju bivanja med anketiranimi v Sloveniji slabih $50 \%$, v Italiji slabih $65 \%$ in na Hrvaškem $67 \%$. Na podoben način lahko deleže rojenih izven območja bivanja ugotovimo še za starše intervjuvanih in njihove zakonce ter na osnovi teh podatkov nato izračunamo še skupno mero mobilnosti za posamezna območja. V splošnem so si razna obmejna območja dokaj sorodna, tako da znaša skupna mera mobilnosti ob slovensko-italijanski meji okrog $60 \%$, ob slovensko-hrvaški meji pa nekaj več kot $35 \%$; v ostali Slovenski Istri je najvišja, sai presega $75 \%$, v "notranjem" delu hrvaške Istre pa rahlo presega $60 \%$. Skupno je ta mera mobilnosti skorajda enaka $v$ slovenskem in italijanskem delu obravnavanega območja (skoraj $60 \%$ ), medtem ko je na hrvaški strani nekoliko nižja (okrog 50 \%). Najbolj dinamično je pri tem urbano območje Slovenske Istre, kamor so se intervjuvanci priselili iz Notranjske, Štajerske, Buzeta in okolice, območja Boršta-Pregare, Goriške in Gorenjske ; pri njihovih očetih prevladujejo območja Buzeta in okolice, širšega območja Brkinov, Goriške, območje Boršta-Pregare, Štajerska, a tudi širše območje Ljubljane, Gorenjske in Krasa; pri materah so izraziteje zastopana območja Goriške, Štajerske, Notranjske, Brkinov in Buzeta, pri zakoncih pa območja Goriške, Ljubljane z okolico, Bosne in Hercegovine, Notranjske in notranje Slovenske Istre.

Še boli kot priselitveno je za obravnavano območje, zlasti za njen obmejni del, značilno izselitveno gibanje prebivalstva, saj se je iz skoraj $75 \%$ v anketo zajetih gospodinjstev eden ali več družinskih članov izselilo iz sedanjega kraja bivanja $v$ nek drug kraj. $\vee$ skupnem pogledu je izseljevanje še zlasti značilno za 
obe strani slovensko-hrvsaškega obmejnega območja in ostalo hrvaško Istro, kjer $\vee$ povprečju ta pojav zadeva okrog $85 \%$ intervjuvanih družin. Na osnovi razmerja med dinamiko priselitev oziroma skupno mero moblinosti in obsegom izselitvenih gibani lahko izvedemo tudi okvirno tipologijo posameznih območii z ozirom na niihovo selitveno bilanco. Slednja dokaj nazorno prikazuje sorodnosti in razlike $v$ migracijski orientaciij posameznih območij istrske "tromeje". V skupnem pogledu po izselitveni praksi dokaj izstopa slovenskohrvaško obmejno območje (tu znaša negativna bilanca na obeh straneh skoraj $50 \%)$ pred slovenskim delom slovensko-italijanskega mejnega območja in "notranjo" hrvaško Istro z negativno bilanco okrog 20 \%. Kot pretežno priselitveni območji se izkažeta preostala Slovenska Istra in italijanski del slovensko-italijanske meje, kjer se pozitivna selitvena bilanca giblje v povprečju med $10 \%$ in $15 \%$. Končna selitvena bilanca po državnih delih pokaže relativno visoko težnjo $k$ izseljevanju na Hrvaškem, rahlo prevlado izselitvenih praks nad priselitvenimi $\vee$ Sloveniji in rahlo prevlado priselitvenih praks nad izselitvenimi v Italiiji.

Pri navedbah krajev oziroma območij, kamor so se družinski člani izseljevali, ni opaziti izrazitejše disperznosti (srednja mera disperznosti je 2,3), kar pomeni, da se je večji del izseljenih družinskih članov izselila $v$ povprečju $v$ dva različna kraja ali območji. $V$ skupnem pogledu po številu navedb prevladuje Trst $(17 \%)$ pred Koprom in drugimi italijanskimi mesti izven Furlanije-Julijske krajine (okrog $10 \%$ navedb). Tem trem glavnim izselitvenim območjem sledijo nato severna Amerika, Ljubljana, Izola, Avstralija, Rijeka, Nemčija, južna Istra, Videm, Argentina, Umag in Milje. Sicer pa je orientacija posameznih obmejnih predelov pri izbiri kraja oziroma območja izselitve nekoliko različna. $V$ slovenskem obmejnem območju z Italijo daleč prevladujeta Trst in Koper (okrog 20 \% navedb) pred Ljubljano in sosednjo občino Dolina, medtem ko prevladuje $v$ slovenskem obmejnem območju s Hrvaško Trst (nad $27 \%$ navedb) pred Koprom in Izolo (od $10 \%$ do $15 \%$ navedb). $\checkmark$ italijanskem obmejnem pasu prav tako izstopa Trst (32\% navedb) pred Avstralijo, Miljami in drugimi mesti v Italiji izven Furlanije-Julijske krajine (vsa tri območja beležijo nekja nad 10\% navedb). V hrvaškem obmejnem pasu pa je izrazitejše izseljevanje $v$ boli oddaljena italijanska mesta izven dežele FurlanijeJulijske krajine (22\% navedb), katerim sledijo Trst, Rijeka, Koper, Videm, mesta v južni Istri, Amerika in Umag (od $5 \%$ do $10 \%$ navedb). Razlike so tudi med urbanim in "notranjim" delom preostale Slovenske Istre : prvi je nekoliko 
izraziteje usmerjen v Ljubljano (15\% navedb), kateri sledijo Koper, Amerika in Trst (od $10 \%$ do $13 \%$ navedb), drugi pa pretežno v Koper (15\% navedb) pred Ameriko, Ljubljano in Trstom (okrog $10 \%$ navedb). Končno daje "notranii" del hrvaške Istre rahlo prednost Trstu (13 \% navedb) pred drugimi italijanskimi mesti izven Furlanije-Julijske krajine, mesti v južni Istri in Ameriko (okrog $10 \%$ navedb). Skupno obsega delež lokalno usmerienih selitvenih gibani v okviru lastnega ali sosednjih obmejnih območij $65 \%$ do $70 \%$ v slovenskem obmejnem pasu z Italijo in Hrvaško, okrog $55 \%$ v italijanskem obmejnem pasu s Slovenijo in le okrog 30 \% v hrvaškem obmejnem pasu s Slovenijo. Manjšo lokalno in čezmejno usmerienost imajo selitveni tokovi $v$ preostali Slovenski Istri, kier znaša ta delež okrog $40 \%$, ter v "notranii" hrvaški Istri, kjer je celo nižji od $25 \%$.

Glede na zgoraj orisano pretežno lokalno usmerienost selitvenih gibani v večjem delu obmejnih območij istrske "tromeje", se osnovne čezmejne vezi obravnavanega prostora nanašajo ravno na obstoj skupnega sorodstvenega omrežja, ki izraža hkrati prostorski obseg preteklih in potencialni obseg sedanjih čezmejnih vezi na družinski ravni. Sorodnike $v$ eni ali obeh sosednjih državah ima namreč skupno $77 \%$ vprašanih, največ, okrog $85 \%$, $v$ slovenskem obmejnem pasu z Italijo in hrvaškem obmejnem pasu s Slovenijo, najmani, od $65 \%$ do $70 \%$, pa $v$ urbanem in notranjem delu Slovenske Istre ter $v$ italijanskem obmejnem pasu s Slovenijo. Skupaj ima $v$ Italiji sorodnike $64 \%$ intervjuvanih v Sloveniji in $71 \%$ vprašanih na Hrvaškem, v Sloveniji $65 \%$ intervjuvanih v Italiii in 45 \% vprašanih na Hrvaškem, ter na Hrvaškem $13 \%$ intervjuvanih v Italiji in $38 \%$ vprašanih v Sloveniji. Ta povprečja kažejo na določeno "gradacijo", ki se jasno sklada s privlačnostjo različnih območij v čezmejnem selitvenem gibanju in se zmanjšuje od Trsta navzdol. Kljub temu pa je določena persistenca teritorialnih vezi in večje čezmejno ravnovesje $\checkmark$ sorodstvenem razmeriu opazno med posameznimi obmejnimi pasovi, kar je mogoče razbrati že iz dejstva, da znašajo deleži sorodnikov na drugi strani meje $65 \%$ na obeh straneh slovensko-italijanske meje, na slovensko-hrvaški meji pa se gibliejo od okrog $40 \%$ na slovenski strani do okrog 45\% na hrvaški. 
Tab. 1 Območja bivanja sorodnikov v sosednjih državah glede na navedbe anketiranih v posameznih enotah istrske "tromeje" (v \%)

\begin{tabular}{|l|c|c|c|c|c|c|}
\hline Območja bivanja sorodnikov & \multicolumn{7}{|c|}{ Območja izvedbe ankete } \\
\hline & A & B & C & D & E & F \\
\hline Sosednji kraji v Italiji & 59,1 & 55,1 & - & 21,7 & 47,2 & 36,9 \\
\hline Sosednji kraji na Hrvaškem & 7,1 & 20,0 & 5,0 & - & 13,9 & - \\
\hline Slovenska Istra & - & - & 60,0 & 23,0 & - & 32,2 \\
\hline Ostala Slovenija & - & - & 26,3 & 14,2 & - & 12,0 \\
\hline Ostala Italija & 6,6 & 7,1 & - & 41,1 & 7,6 & 18,9 \\
\hline Ostala Hrvaška & 27,2 & 17,8 & 8,7 & - & 31,3 & - \\
\hline Skupai & 100,0 & 100,0 & 100,0 & 100,0 & 100,0 & 100,0 \\
\hline
\end{tabular}

A - Slovenski obmejni pas z Italijo;

B - Slovenski obmejni pas s Hrvaško;

C - Italijanski obmejni pas s Slovenijo;

D - Hrvaški obmejni pas s Slovenijo;

E - Notranji del Slovenske Istre;

F - Notranji del hrvaške Istre.

Če sta nam obstoj in razširjenost čezmejnih sorodstvenih vezi prikazala eno plast strukture obmejnih stikov, nam podobno in $v$ marsičem komplementarno podobo te strukture daje tudi mreža čezmejnih poznanstev. V tem pogledu nas je prav tako zanimala prostorska distribucija čezmejnih osebnih vezi, ki za razliko od sorodstvenih, ki nekako nakazujejo potencialni obseg čezmejnih vezi, predstavljajo $v$ nekoliko vernejši obliki to, kar bi lahko imenovali "vsakdanji" obseg čezmejnega komuniciranja. Skupno ima znance $v$ eni ali obeh sosednijh državah istrske "tromeje" 77 \% vprašanih, največ v hrvaškem obmejnem pasu s Slovenijo in slovenskem obmejnem pasu z Italijo (skoraj $90 \%$ ), najmani pa $v$ urbanem in notranjem delu Slovenske Istre (okrog $65 \%$ ). Struktura osebnih čezmejnih vezi po kraju bivanja znancev pa je precej različna v posameznih območjih : v Italiji ima znance 77 \% vprašanih na Hrvaškem in $58 \%$ vprašanih v Sloveniii; v Sloveniii ima znance $75 \%$ vprašanih v Italiji in $71 \%$ na Hrvaškem; na Hrvaškem pa komaj 46 \% vprašanih v Sloveniii in slabih 38 \% vprašanih v Italiji. Pri tem opažamo večje sorazmerje za slovensko-italijansko obmejno območje, kjer ima na sosedni strani meje znance $v$ povprečju od $75 \%$ do $80 \%$ vprašanih, medtem ko ima na slovensko-hrvaškem mejnem odseku na hrvaški strani znance $v$ sosednji državi skoraj 75 \% vprašanih, na slovenski strani pa komaj nad 50 \% vprašanih. 
Na obeh straneh tega mejnega odseka prevladuje usmerienost do italijanskih sosedov, kjer ima znance skoraj $55 \%$ vprašanih v Sloveniii in skoraj $85 \%$ vprašanih na Hrvaškem. Iz tega izhaja, da ima med obravnavanimi obmejnimi območji najmanjšo predispozicijo do vzpostavljanja osebnih čezmejnih vezi slovenski obmejni pas s Hrvaško. Podobno "zadržanost" odkrijemo $\checkmark$ preostalem območju Slovenske Istre, kjer ima v Italiji znance okrog $50 \%$ vprašanih, na Hrvaškem pa 45 \% vprašanih, ter v "notranji" hrvaški Istri, kjer ima znance v Sloveniij oziroma Italiji okrog $60 \%$ vprašanih.

Tab. 2: Območja bivanja znancev v sosednjih državah glede na navedbe anketiranih v posameznih enotah istrske "tromeje" (v \%)

\begin{tabular}{|l|c|c|c|c|c|c|}
\hline Območja bivanja znancev & \multicolumn{7}{|c|}{ Območja izvedbe ankete* } \\
\hline & A & B & C & D & E & F \\
\hline Sosednji kraji v Italiji & 58,7 & 46,5 & - & 27,1 & 44,1 & 40,8 \\
\hline Sosednji kraji na Hrvaškem & 14,5 & 41,6 & 17,7 & - & 19,9 & - \\
\hline Slovenska Istra & - & - & 49,6 & 35,7 & - & 36,8 \\
\hline Ostala Slovenija & - & - & 16,4 & 11,9 & - & 15,4 \\
\hline Ostala Italija & 5,7 & 4,2 & - & 25,3 & 9,6 & 7,0 \\
\hline Ostala Hrvaška & 21,1 & 7,7 & 16,3 & - & 26,4 & - \\
\hline Skupai & 100,0 & 100,0 & 100,0 & 100,0 & 100,0 & 100,0 \\
\hline
\end{tabular}

${ }^{*}$ Glej legendo pri tabeli 1

Primerjava med strukturo "vsakdanjega" akcijskega radija obmejnega prebivalstva, kakršnega ponazarja $v$ grobem dimenzija medosebnih čezmejnih vezi, in "potencialnim" obsegom tega akcijskega radija, ki ga nekako predstavljajo obstoječe sorodstvene vezi, ne odkriva velikih razlik. V povprečju imajo vprašani $63 \%$ sorodnikov in $73 \%$ znancev v bližnjem čezmejnem okolju oziroma v okviru same istrske "tromeje". Nekoliko višji deleži so prisotni v slovenskem obmejnem pasu s Hrvaško, ki je zato najbolj "lokalistično" usmerjen, opazneje nižji deleži, zlasti glede na kraj bivanja sorodnikov, pa so prisotni $v$ njegovi neposredni soseščini, se pravi v hrvaškem obmejnem pasu $s$ Slovenijo, ki je zaradi večje selitvene dinamike tudi prostorsko bolj odprt v oblikovanju sorodstvenih in osebnih čezmejnih vezi. 
Tab. 3: Primeriava čezmejnih prostorskih akcijskih radijev prebivalcev istrske "tromeje" glede na kraj bivanja sorodnikov in znancev ( $v$ \%)

\begin{tabular}{|l|c|c|c|c|c|c|c|c|c|c|}
\hline \multirow{2}{*}{ Območje } & \multicolumn{2}{|c|}{1} & \multicolumn{2}{|c|}{2} & \multicolumn{2}{c|}{3} & \multicolumn{3}{c|}{4} & \multicolumn{2}{c|}{5} \\
\cline { 2 - 13 } & $\mathrm{a}$ & $\mathrm{b}$ & $\mathrm{a}$ & $\mathrm{B}$ & $\mathrm{a}$ & $\mathrm{b}$ & $\mathrm{a}$ & $\mathrm{b}$ & $\mathrm{a}$ & $\mathrm{b}$ \\
\hline It.obm.pas s SI. & 50 & 60 & 18 & 5 & 16 & 26 & 16 & 9 & 68 & 65 \\
\hline Sl.obm.pas z It. & 59 & 59 & 15 & 7 & 6 & 7 & 21 & 27 & 74 & 66 \\
\hline Sl.obm.pas s Hr. & 42 & 20 & 47 & 55 & 8 & 18 & 4 & 7 & 89 & 75 \\
\hline Hr.obm.pas s SI. & 36 & 23 & 27 & 22 & 12 & 14 & 25 & 41 & 63 & 45 \\
\hline Ost.Slov.Istra & 44 & 47 & 20 & 14 & 10 & 8 & 26 & 31 & 64 & 61 \\
\hline Ost.Hrv.Istra & 37 & 32 & 41 & 37 & 15 & 12 & 7 & 19 & 78 & 69 \\
\hline Skupaj & 45 & 40 & 28 & 23 & 11 & 14 & 17 & 22 & 73 & 63 \\
\hline
\end{tabular}

1 - Bližnje območje sosednje države (pri ostali Slovenski Istri je to Italija) ;

2 - Bližnje območje "tretje" države (za slovenski obmejni pas s Hrvaško je to na primer Italija) ;

3 - Ostalo območje sosednje države ;

4 - Ostalo območje "tretje" države;

5 - Srednja mera lokalne čezmejne povezanosti (seštevek navedenih deležev sorodnikov ali znancev v bližnjem območju sosednje in "tretje" države) ;

a - Znanci ;

b - Sorodniki

\section{Struktura funkcionalne povezanosti obmejnega prostora}

Po pregledu osnovnih struktur čezmejne povezanosti, ki temeliijo na obstoju sorodstvenih in drugih medosebnih vezi ter predstavljajo nekakšno temeljno podlago pri razvoju dejanskih oblik čezmejnih odnosov in izmenjav, bomo sedai pri obravnavi oblik funkcionalne povezanosti najprej nekoliko pobliže pogledali, kakšna je bila v okviru zgoraj opisane splošne družbene povezanosti obravnavanega obmejnega območja intenziteta in tipologija čezmejnega obiskovanja. Glede na skupne navedbe je večina anketiranih oseb v istrski "tromeji" navedla, da kraje v sosednjih državah obiskuje enkrat mesečno ali redkeje (43\%). Tej skupini po pomenu sledijo tisti, ki sosednje kraje obiskujejo dvakrat do trikrat mesečno (29 \%), medtem ko deleži navedb pogostejših obiskov (okrog $15 \%$ ) odgovarjajo deležem tistih, ki sosednje kraje ne obiskujejo nikoli. Seveda pa se navedbe pogostosti obiskovanja sosednjih krajev dokaj razlikujejo med posameznimi območji po izvoru in destinaciji čezmejnih gibanj, kakor je razvidno iz naslednje tabele. 
Tab. 4 Pogostost obiskovanja čezmejnih krajev v istrski "tromeji" (v \%)

\begin{tabular}{|c|c|c|c|c|c|c|c|}
\hline \multicolumn{8}{|c|}{ a) po območjih destinacije } \\
\hline Območje destinacije & 1 & 2 & 3 & 4 & 5 & 6 & skupaj \\
\hline Italija & 2,7 & 5,5 & 12,2 & 37,2 & 38,5 & 4,0 & 100,0 \\
\hline Slovenija & 2,3 & 4,1 & 10,9 & 38,5 & 34,6 & 9,6 & 100,0 \\
\hline Hrvaška & 0,2 & 1,0 & 2,5 & 9,3 & 56,2 & 30,9 & 100,0 \\
\hline Skupaj & 1,8 & 3,7 & 8,9 & 28,9 & 43,0 & 13,7 & 100,0 \\
\hline
\end{tabular}

\begin{tabular}{|l|c|c|c|c|c|c|c|}
\hline b) po območiih, kier so bile opravljene ankete \\
\hline Območje bivanja & 1 & 2 & 3 & 4 & 5 & 6 & Skupai \\
\hline Ital. del & 0,6 & 5,1 & 10,2 & 19,3 & 52,3 & 12,5 & 100,0 \\
\hline Slov. del & 2,0 & 4,6 & 9,2 & 15,6 & 50,3 & 18,3 & 100,0 \\
\hline Hrv. del & 2,0 & 2,2 & 8,0 & 49,3 & 30,6 & 7,9 & 100,0 \\
\hline Skupai & 1,8 & 3,7 & 8,9 & 28,9 & 43,0 & 13,7 & 100,0 \\
\hline
\end{tabular}

1 - Vsak dan ;

$2-2 x-3 x$ tedensko;

3 - $1 x$ tedensko;

$4-2 x-3 x$ mesečno ;

5 - Redkeje ;

6 - Nikoli.

Iz zgornje tabele razberemo kar nekaj informacij: glede destinacije čezmejnih gibani je zanimivo, da se obravnavano območje razdeli dve dokaj ločeni enoti, in sicer območji Italije in Slovenije na eni strani, kamor gredo intervjuvani v veliki večini nekajkrat mesečno ali občasno (do $75 \%$ navedb), medtem ko obsegajo navedbe pogostejših obiskov do $20 \%$ primerov (od tega odpade na tedenske obiske okrog $10 \%$ navedb, na večkratne obiske $v$ tednu ali dnevne obiske pa do $10 \%$ navedb). Na drugi strani je območje Hrvaške, kamor gre večina (nad $55 \%$ ) intervjuvanih iz sosednjih območij istrske "tromeje" le občasno, se pravi enkrat mesečno ali redkeje, nikoli pa skoraj tretjina vprašanih. Ker je to očitno bolj destinacija letnih počitniških bivanj kot pa sprotnih funkcionalnih obiskov, so navedbe pogostejših obiskov redkejše in obsegajo do $10 \%$ primerov pri potovanjih, ki se ponavljajo nekajkrat mesečno, in samo do $5 \%$ pri rednih tedenskih ali dnevnih obiskih.

Različna je tudi orientacija intervjuvanih $v$ italijanskem, slovenskem in hrvaškem delu istrske "tromeje" pri navajanju pogostosti čezmejnih obiskov. Intervjuvani v Italiji in Sloveniji imajo glede tega boli sorodne navade: dnevni ali večkrat tedenski čezmejni obiski obsegajo pri njih nekaj mani kot $5 \%$ navedb, enkrat tedenski približno $10 \%$ navedb, večkrat mesečni med 15\% in 
20\% navedb, redkejši obiski približno $50 \%$ navedb, nikoli pa ne obiskuje sosednjih krajev približno 15 \% vprašanih. Pri intervjuvanih na Hrvaškem so večkrat tedenska ali dnevna potovanja $v$ eno ali drugo sosednjo državo obsegala do $5 \%$ navedb, enkrat tedenski obiski do $10 \%$, večkrat mesečni približno $50 \%$, redkejši pa okrog 30\% navedb; nikoli ne obiskuje sosednjih krajev tu manj kot $10 \%$ vprašanih. Iz tega lahko sklepamo, da so prebivalci hrvaškega dela Istre rednejši obiskovalci krajev v sosednjih državah kot prebivalci slovenskega in italijanskega dela tega območja, kjer prevladujejo sporadične oblike čezmejnih obiskov, čeprav so pri njih $v$ primerjavi z intervjuvanimi na Hrvaškem nekoliko številnejši primeri rednih tedenskih ali celo dnevnih obiskov.

Poleg frekvence obiskovanja sosednjih krajev pa nas je zanimal še en vidik časovne distribucije čezmejnega prometa, to je njegova razporeditev $v$ tednu oziroma med delavnike in praznike. $V$ tem pogledu obstajajo med območji precejšnje razlike: intervjuvani na Hrvaškem so obe sosednji državi obiskovali pretežno ob delavnikih (od $45 \%$ do $50 \%$ navedb), tako kot so delavnike izbirali za svoja potovanja $\vee$ Italijo tudi intervjuvani v Sloveniji (okrog $50 \%$ navedb), medtem ko je Hrvaška za intervjuvane v Italiji in Sloveniji, kakor smo nakazali že zgoraj, očitno destinacija prostega časa, saj tja potuje ob koncu tedna ali ob praznikih skoraj $65 \%$ vprašanih v Sloveniii in nad $75 \%$ vprašanih v Italiji; Slovenija je, končno, za vprašane v Italiji destinacija čezmejnih obiskov tako ob delavnikih kot praznikih za $45 \%$ vprašanih in samo ob koncu tedna oziroma praznikih za nekaj več kot $40 \%$ vprašanih.

Tab. 5: Čas obiskovanja sosedniih čezmejnih krajev po območjih istrske "tromeje" (v \%)

\begin{tabular}{|l|c|c|c|c|}
\hline $\begin{array}{l}\text { Območje } \\
\text { bivanja }\end{array}$ & $\begin{array}{c}\text { Območje } \\
\text { destinacije }\end{array}$ & Ob delavnikih & $\begin{array}{c}\text { Ob praznikih/ } \\
\text { vikendih }\end{array}$ & $\begin{array}{c}\text { Ob delavnikih } \\
\text { in praznikih }\end{array}$ \\
\hline \multirow{2}{*}{ Ital. del } & Slovenija & 12,6 & 42,5 & 44,9 \\
\cline { 2 - 5 } & Hrvaška & 5,0 & 76,7 & 18,3 \\
\hline \multirow{2}{*}{ Slov. del } & Italija & 48,8 & 17,5 & 33,7 \\
\cline { 2 - 5 } & Hrvaška & 13,1 & 62,7 & 24,2 \\
\hline \multirow{2}{*}{ Hrv. del } & Italija & 47,8 & 35,5 & 16,7 \\
\cline { 2 - 5 } & Slovenija & 44,6 & 37,7 & 17,7 \\
\hline
\end{tabular}


Če deleže "indiferentnih" iz zgornje tabele enakomerno razporedimo med delavnike in praznike, ugotovimo, da je Italija predvsem destinacija "poslovnih" obiskov za intervjuvane v Sloveniji, saj delavniki na ta način zavzemajo dve tretjini navedb; isti obseg navedb, a tokrat za praznike in vikende, zabeležimo pri obiskih Slovenije med anketiranimi v Italiji. Intervjuvani na Hrvaškem skorajda enakomerno delijo svoje obiske krajev $v$ Italiji in Sloveniii med delavnike (okrog $55 \%$ navedb) in praznike oziroma vikende (okrog $45 \%$ navedb), medtem ko je Hrvaška tako za intervjuvane v Italiji kot Sloveniii v veliki meri destinacija prostega časa s $75 \%$ navedb v Slovenski Istri in nad $85 \%$ navedb v italijanskem obmejnem območju.

lz zgornjega pregleda je prišlo jasno do izraza, da precejšen del tukajšnjega prebivalstva redno ali občasno posega $v$ sosednii obmejni prostor pri zadovoljevanju vrste pomembnih dejavnosti. Zaradi tega je za poglobljeno poznavanje obravnavanega obmejnega območja potrebno, da ugotovimo še vzroke čezmejnega obiskovanja, kar nam nedvomno razkriva nove aspekte čezmejnega povezovanja, $v$ kombinaciji s prostorsko dimenzijo pa nam daje tudi potrebne elemente za določevanje osnovnih oblik funkcionalne organizacije same istrske "tromeje".

Izhajajoč iz dosedanje izkušnje pri obravnavi obmejnih območii in funkcionalnih aspektov čezmejnega povezovanja smo tudi na primeru istrske "tromeje" izdvojili sedem različnih motivacijskih sklopov, in sicer obisk sorodnikov (in znancev), nakupe, obisk gostiln, oskrbo z bencinom, delo, izlet (in rekreaciio) ter druge vzroke. Kakor je razvidno iz naslednje tabele, prevladujejo pri obiskih krajev $\vee$ Italiji med intervjuvanimi $v$ Sloveniii in na Hrvaškem primarno motivi nakupov, ki nastopajo v povprečju pri $85 \%$ primerov v Sloveniji in kar v $93 \%$ primerov na Hrvaškem, sekundarno pa motivi obiska sorodnikov (in znancev), katere navaja $\vee$ povprečju $43 \%$ anketiranih $v$ Sloveniji in $58 \%$ vprašanih na Hrvaškem. V manǰ̌i meri nastopa kot motiv potovanja v Italijo še "delo" (pri $19 \%$ vprašanih v Sloveniii in 11 \% vprašanih na Hrvaškem) in "izlet" (pri 13 \% vprašanih v Sloveniii in $12 \%$ vprašanih na Hrvaškem).

Pri motivih obiska krajev v Sloveniii je struktura navedb med vprašanimi v Italiji in na Hrvaškem dokaj različna. Intervjuvani v italijanskem delu istrske "tromeje" so izpostavljali zlasti motive "izleta" in "oskrbe z bencinom" (med $70 \%$ in $75 \%$ primerov) pred "obiskom sorodnikov" (okrog $35 \%$ primerov), "obiskom gostiln" (okrog $25 \%$ primerov), "nakupi" (okrog $20 \%$ primerov), "delom" in drugimi vzroki (med $5 \%$ in $10 \%$ primerov). Med intervjuvanimi na Hrvaškem prevladujeta 
motiva "nakupov" (65 \% primerov) in "obiska sorodnikov" (40\% primerov) pred "izletom" (15\% primerov), "delom" in "oskrbo z bencinom" (med $5 \%$ in $10 \%$ primerov). Spet drugačne so navedbe najboli pogostih motivov obiska krajev na Hrvaškem med vprašanimi v italijanskem in slovenskem delu istrske "tromeje", pri čemer ne prihaja samo do razlik $v$ tipologiji navedb, ampak tudi do različne intenzivnosti samih navedb. Intervjuvani $v$ Italiji so tako izpostavili zlasti motiv "izleta" (nad $65 \%$ primerov) pred "obiski sorodnikov" in "obiskom gostiln" (okrog $10 \%$ primerov), medtem ko so intervjuvani v Sloveniji kot primarni in skorajda edini vzrok potovanja na Hrvaško enakovredno omenjali motiva "obiska sorodnikov" in "izleta", ki pa sta obsegala le manj kot $35 \%$ primerov. To pomeni, da so bili prebivalci Slovenske Istre le malo zainteresirani za potovanja v svojo južno soseščino ne glede na izbran motiv.

Tab. 6: Motivi obiska čezmejnih krajev po osnovnih enotah istrske "tromeje" ( $\mathrm{\%}$ )*

\begin{tabular}{|l|c|c|c|c|c|c|c|}
\hline 1) Motivi obiska krajev v ltaliji \\
\hline Teritorialne enote & 1 & 2 & 3 & 4 & 5 & 6 & 7 \\
\hline Slovenska Istra & 43 & 85 & 1 & 0 & 19 & 13 & 3 \\
\hline Hrvaška Istra & 58 & 93 & 0 & 1 & 11 & 12 & 1 \\
\hline \multicolumn{7}{|l|}{ 2) Motivi obiska krajev v Sloveniji } \\
\begin{tabular}{|l|c|c|c|c|c|c|c|}
\hline Teritorialne enote & 1 & 2 & 3 & 4 & 5 & 6 & 7 \\
\hline Sosednja Italija & 36 & 19 & 23 & 72 & 9 & 74 & 7 \\
\hline Hrvaška Istra & 40 & 65 & 2 & 7 & 9 & 15 & 2 \\
\hline $\begin{array}{l}\text { 3) Motivi obiska krajev na Hrvaškem } \\
\text { Teritorialne enote }\end{array} 1$ & 2 & 3 & 4 & 5 & 6 & 7 \\
\hline Sosednia Italija & 10 & 3 & 11 & 0 & 0 & 67 & 0 \\
\hline Slovenska Istra & 33 & 3 & 6 & 0 & 1 & 32 & 2 \\
\hline
\end{tabular}
\end{tabular}

1 - Obisk sorodnikov in znancev;

2 - Nakupi ;

3 - Obisk gostiln :

4 - Oskrba z bencinom;

5 - Delo;

6 - Izlet;

7 - Drugi vzroki.

* Ker so lahko anketirani navedli več kot en motiv, seštevek vseh deležev presega $100 \%$.

Iz preglednice razberemo, da po lastnih navedbah okrog $45 \%$ družin v Slovenski Istri potuje v Italijo zaradi obiska sorodnikov, $85 \%$ jih tam kupuje, 
skoraj $20 \%$ ima enega ali več članov, ki v sosednji državi opravlja plačano delo (v enoti Krkavče-Koštabona ta delež presega $45 \%$ ), skorai $15 \%$ pa se tja odpravlja tudi na izlet. Med anketiranimi družinskimi okolji na Hrvaškem jih okrog $95 \%$ potuje v Italijo zaradi nakupov, skoraj $60 \%$ zaradi obiska sorodnikov, nad $10 \%$ se tja podaja na izlet, isti delež gospodinjstev pa ima tudi enega ali več članov, ki v tej državi opravlja plačano delo. Skoraj $75 \%$ družinskih okoljih v italijanskem delu istrske "tromeje" obiskuje Slovenijo zaradi izleta ali oskrbe z bencinom, dobra tretjina zaradi obiska sorodnikov, slaba četrtina zaradi obiska gostiln in petina zaradi nakupov. $V$ hrvaškem delu tega območja je $65 \%$ družinskih okolij navedlo za vzrok potovanja v Slovenijo nakupe, $40 \%$ obisk sorodnikov, $15 \%$ izlet, $10 \%$ pa delo enega ali več svojih članov. Nad $65 \%$ anketiranih družin v Italiji potuje na Hrvaško zaradi izleta, okrog $10 \%$ pa zaradi obiska sorodnikov in obiska gostiln. Hrvaško pa zaradi izleta in obiska sorodnikov obiskuje le tretjina družinskih okolij v Slovenski Istri.

Iz povedanega izhaja obenem, da so izbrani motivi obiska sosednjih krajev dokaj različno pomembni za posamezne dele istrske "tromeje", kar pomeni, da so izraziteje zastopani samo $v$ nekaterih delih tega obmejnega območja. Da bi lažje ugotovili sorodnosti in razlike $\vee$ funkcionalni strukturi čezmejnih potovani, smo deleže navedb za vsak posamezen motiv združili in na ta način izračunali skupne deleže navedb motivov obiska sosednjih krajev po območjih izvedbe ankete ter skupne tendenčne motivacije za odhod oziroma prihod $v$ posamezne dele istrske "tromeje".

Tab. 7: Funkcionalna struktura posameznih delov istrske "tromeje" po deležih skupnih navedb vzrokov obiska sosednjih obmejnih območij ( $v$ \%)

\begin{tabular}{|c|c|c|c|c|c|c|c|c|}
\hline \multicolumn{9}{|c|}{ 1) skupni deleži navedb motivov obiska sosednjih krajev po območjih izvedbe ankete } \\
\hline \multirow{2}{*}{ Motivi } & \multirow{2}{*}{\begin{tabular}{|l|}
$A$ \\
$B$ \\
\end{tabular}} & \multicolumn{2}{|c|}{ Ital.del } & \multicolumn{2}{|c|}{ Slov.del } & \multicolumn{2}{|c|}{ Hrv.del } & \multirow{2}{*}{$\begin{array}{c}\text { Skupai } \\
\text { istrska "tromeja" }\end{array}$} \\
\hline & & SI. & $\mathrm{Hr}$. & It. & $\mathrm{Hr}$. & It. & SI. & \\
\hline Obisk sorod. & & 15,1 & 11,4 & 25,7 & 39,9 & 33,8 & 26,5 & 25,4 \\
\hline Nakupi & & 8,0 & 2,5 & 53,4 & 3,1 & 51,6 & 50,0 & 28,1 \\
\hline Obisk gostiln & & 9,5 & 11,4 & 0,5 & 9,6 & 0,2 & 1,3 & 5,4 \\
\hline Bencin & & 29,7 & 0,0 & 0,0 & 0,0 & 0,9 & 5,4 & 6,0 \\
\hline Delo & & 3,8 & 0,0 & 11,0 & 1,6 & 5,7 & 5,4 & 4,6 \\
\hline Izlet & & 31,1 & 74,7 & 7,4 & 43,0 & 6,7 & 9,5 & 28,7 \\
\hline Drugo & & 2,8 & 0,0 & 2,0 & 2,8 & 1,1 & 1,9 & 1,8 \\
\hline Skupai & & 100,0 & 100,0 & 100,0 & 100,0 & 100,0 & 100,0 & 100,0 \\
\hline
\end{tabular}

A - območje bivanja; B - območje destinacije 


\begin{tabular}{|l|c|c|c|c|c|c|}
\hline 2) Skupne tendenčne motivacije za odhod in prihod iz/v posamezne dele istrske "tromeje" \\
\hline Motivi & \multicolumn{2}{|c|}{ Ital.del } & \multicolumn{2}{c|}{ Slov.del } & \multicolumn{2}{c|}{ Hrv.del } \\
\hline & Odh. & Prih. & Odh. & Prih. & Odh. & Prih. \\
\hline Obisk sorod. & 13,2 & 29,8 & 32,8 & 20,8 & 30,1 & 25,6 \\
\hline Nakupi & 5,2 & 52,5 & 28,3 & 29,0 & 50,8 & 2,8 \\
\hline Obisk gostiln & 10,5 & 0,3 & 5,0 & 5,4 & 0,7 & 10,5 \\
\hline Bencin & 14,9 & 0,4 & 0,0 & 17,6 & 3,2 & 0,0 \\
\hline Delo & 1,9 & 8,4 & 6,3 & 4,6 & 5,6 & 0,8 \\
\hline Izlet & 52,9 & 7,0 & 25,2 & 20,3 & 8,1 & 58,9 \\
\hline Drugo & 1,4 & 1,6 & 2,4 & 2,3 & 1,5 & 1,4 \\
\hline Skupai & 100,0 & 100,0 & 100,0 & 100,0 & 100,0 & 100,0 \\
\hline
\end{tabular}

Iz zgornje preglednice lahko razberemo, da je med intervjuvanimi $v$ italijanskem delu istrske "tromeje" glavni vzrok obiska krajev v Sloveniji kombinacija motivov "izlet" in "oskrbovanje z bencinom", ki skupaj presegata $60 \%$ navedb, tema dvema motivoma pa sledijo po pomenu "obisk sorodnikov" (15\% navedb), "obisk gostiln" (10\%) in "nakupi" (8\%); preostala dva motiva beležita od $3 \%$ do $4 \%$ navedb. Povsem drugače je pri motivih obiska krajev na Hrvaškem, kier daleč prevladuje kategorija "izleta" s 75 \% vseh navedb pred "obiskom sorodnikov" in "obiskom gostiln", ki beležita po $10 \%$ navedb. Intervjuvani v Slovenski Istri gredo v Italijo pretežno po nakupe (skorai $55 \%$ navedb), v manjši meri pa še obiskat sorodnike (okrog $25 \%$ navedb), na delo (nad $10 \%$ ) in izlet (7\% navedb). Motiva "izleta" in "obiska sorodnikov" prevladujeta pri vzrokih za pot na Hrvaško (od $40 \%$ do $45 \%$ navedb), katerima se $v$ skromnejši meri pridružuje še kategorija "obiska gostiln" (10 \% navedb). Končno intervjuvani v hrvaškem delu istrske "tromeje" gredo tako v Italijo kot Slovenijo pretežno po nakupih (okrog $50 \%$ navedb) in na obisk k soordnikom (od $25 \%$ do $35 \%$ navedb), v manjši meri pa tudi na izlet (med $5 \%$ in $10 \%$ navedb), na delo (nad $5 \%$ navedb); dodaten motiv, vendar le za pot v Slovenijo, je oskrba z bencinom (nad $5 \%$ navedb).

Glede skupnih tendenčnih motivacii za pot izven oziroma $v$ posamezen del istrske "tromeje" pa lahko ugotovimo, da odhajajo iz italijanskega dela obravnavanega obmejnega območja na obisk sosednjih krajev v Sloveniji in na Hrvaškem pretežno zaradi prostočasnih vzrokov (kategorija "izleta" presega skupaj $50 \%$ navedb), sekundarno pa še zaradi oskrbe z bencinom, obiska sorodnikov in obiska gostiln, medtem ko med motivi obiska krajev v Italiji pri niihovih sosedih so pretežno nakupi (nad 50 \% navedb) in obisk sorodnikov 
(30 \% navedb), v manjši meri še delo (nad $8 \%$ navedb) in izlet (7 \%). Prebivalci Slovenske Istre potujejo $v$ severno in južno soseščino zaradi kombinacije naslednjih motivov: obiska sorodnikov (nad $30 \%$ navedb), nakupov in izleta (nad $25 \%$ navedb), medtem ko to območje privablja sosede zaradi nakupov (skoraj 30 \% navedb), obiska sorodnikov in izleta (nad $20 \%$ navedb) in oskrbe z bencinom (nad $15 \%$ navedb). Prebivalce hrvaškega dela istrske "tromeje" privabliajo kraji v Sloveniji in Italiji zlasti zaradi nakupov (nad $50 \%$ navedb) in obiska sorodnikov (30 \% navedb), medtem ko je hrvaška Istra zanimiva za svoje sosede kot izletniško območje (skoraj 60 \% navedb), $\checkmark$ manjši meri pa še zaradi obiska sorodnikov (nad $25 \%$ navedb) in obiska gostiln (nad $10 \%$ navedb).

Razmerje med motivi odhoda in prihoda $v$ posamezna območja istrske "tromeje" nam razkrijejo, da ima italijanski del izrazit suficit pri kategorijah "obisk sorodnikov", "delo" in zlasti pri "nakupih", deficitarno pa je zlasti pri prostočasnih dejavnostih in nakupu bencina. Slovensko območje izkazuje uravnoteženo razmerje pri kategorijah "nakupi", "obisk gostiln" in "delo", izrazit suficit pri nakupu bencina, deficit pa pri "obisku sorodnikov" in "izletih". Na drugem ekstremu je hrvaško območje, ki je močno deficitno pri kategorijah "nakupi", "delo", rahlo deficitno pa tudi pri "obisku sorodnikov" in "bencinu", medtem ko izkazuje opaznejši suficit pri "izletih" in "obisku gostiln". Zaradi tega lahko italijanski del obravnavanega območja opredelimo kot centralni, slovenski kot polperiferni, hrvaški pa kot periferni del istrske "tromeje". Končno izhaja iz povedanega, da pri motivih obiska sosednjih krajev na območju istrske "tromeje" v skupnem pogledu izstopajo trije motivi, ki obsegajo med $25 \%$ in $30 \%$ navedb, in sicer "izlet", "nakupi" in "obisk sorodnikov", medtem ko se ostali motivi gibljejo okrog $5 \%$ skupnih navedb.

\section{Zaključek in primerjava $z$ goriškim obmejnim območjem}

Raziskovanje slovenskih obmejnih območij z uporabo enotne metodologije nam omogoča tudi medsebojno primerjanje. Trenutno je primerjava obravnavane istrske "tromeje" možna le z goriškim obmejnim območjem (Bufon, 1995) na področju slovensko-italijanskih čezmejnih vezi, v zaključku naše raziskave pa bo primerjavo mogoče opraviti med vsemi slovenskimi obmejnimi območji. Primerjava $z$ goriško obmejno regijo je zanimiva, 
saj sodita obe $v$ južni, urbanizirani del slovensko-italijanske meje, $v$ obeh pa sta zastopani tudi nacionalni manjšini, in sicer slovenska v Italiji na Goriškem in italijanska $v$ Sloveniji $v$ Istri. Kljub temu so razmere, intenzivnost in tipologija čezmejnih vezi med obema območjema dokaj različne.

$\checkmark$ vidiku priseljevanja družinskih članov opažamo, da je stopnja mobilnosti večja v Istri, kjer znaša od $58 \%$ do $59 \%$, kot na Goriškem, kjer se giblje med $43 \%$ in $49 \%$. Podobno je z izseljevanjem, zlasti na italijanski strani istrskega obmejnega območja, kjer znaša srednji delež družin z izseljenimi družinskimi člani nad $75 \%$, medtem ko na slovenski strani isti delež ne presega $50 \%$. $\checkmark$ teh okvirih se nekako giblje tudi isti delež $v$ goriškem obmejnem območju (45\% na italijanski strani in $53 \%$ na slovenski strani). V nasprotju z višjo mobilnostjo, pa imajo intervjuvani $\vee$ Istri na sosedni strani meje mani sorodnikov kot vprašani na Goriškem. V povprečju ima sorodnike na drugi strani meje namreč okrog $85 \%$ vprašanih $\vee$ goriškem obmejnem območju (80\% vprašanih na italijanski strani in $86 \%$ vprašanih na slovenski strani), vzdolž slovensko-italijanske meje v Istri pa le okrog $65 \%$ vprašanih, brez večjih odstopani med obema deloma. Podobno velja za znance: slednje ima na drugi strani meje več kot 90 \% vprašanih na obeh straneh meje na Goriškem, $\checkmark$ istrskem delu slovensko-italijanske meje pa se isti delež giblje med $75 \%$ in $80 \%$. Na ta način znaša skupna mera čezmejne družbene povezanosti na Goriškem skoraj 70 \%, v Istri pa mani kot $60 \%$. Temelina razlika med obema območjema pa je v tem, da na Goriškem močno izstopajo lokalne vezi, v Istri pa regionalne, ki presegajo ožji obmejni pas.

$\checkmark$ pogledu funkcionalnih čezmejnih vezi oziroma intenzivnosti čezmejnih stikov so razlike še bolj očitne. Na Goriškem namreč obiskuje kraje na drugi strani meje enkrat tedensko ali pogosteje nad $60 \%$, v Istri pa manj kot $15 \%$ vprašanih. Tu so tudi izraziteje $\vee$ prevladi obiski ob praznikih ali vikendih (45\%), medtem ko na Goriškem prevladujejo obiski ob delavnikih (60 \%). Temu ustrezni so tudi različni motivi obiska krajev na drugi strani meje in s tem funkcionalna struktura posameznih delov slovensko-italijanske meje. Med respondenti $v$ italijanskem delu Istre za obisk slovenske strani prevladuje kombinacija motivov "izlet" in "oskrba z bencinom" (okrog 30 \% navedb), med respondenti italijanskega dela Goriške pa "obisk sorodnikov" in "nakupi" (okrog $23 \%$ navedb). Med respondenti v slovenskem delu Istre pri motivih obiska italijanske strani izrazito prevladuje motiv "nakupov" (54 \%), ki še boli izstopa kot na Goriškem (44 \%), v ostalem se motivi ne razlikujejo veliko, 
še posebno glede obiska sorodnikov, ki obsega od $26 \%$ do $27 \%$ odgovorov $v$ obeh območjih, medtem ko je motiv "dela" v nekoliko večji meri zastopan na Goriškem (14\%) kot v Slovenski Istri (1 $1 \%)$.

Skratka, istrsko obmejno območje je $v$ primerjavi z goriškim demografsko bolj dinamično, vendar je $v$ pogledu čezmejnih vezi tudi veliko bolj tranzitno in ne dosega intenzivnosti lokalnih izmenjav goriškega obmejnega območja. Značilno je tudi, da so tu pred družbeno-kulturnimi $v$ ospredju funkcionalni vidiki čezmejnega obiskovanja, ki se izvajajo $v$ širšem regionalnem kontekstu in ne le $v$ ožjem obmejnem pasu. Upoštevajoč še hrvaški del, pa postaja istrsko obmejno območje tudi mnogo bolj kompleksno, zaradi česar ga je tudi težko enačiti z drugimi "normalnimi" slovenskimi obmejnimi območji.

\section{Viri in literatura}

Bufon M., 1993: Istra - novi problemi starih regii, Koper, Annales 3, str. 197-202. Bufon M., 1995: Prostor, meje, ljudje. Trst, SLORI in ZIFF, 439 str.

Bufon M., 1997: Geopolitical and ethnic transformations in the Upper Adriatic between conflicts and integration perspectives, Koper, Annales 10, str. 295-306.

\section{DEVELOPMENT OF CROSS-BORDER RELATIONS IN THE ISTRIAN THREE-BORDER AREA BETWEEN SLOVENIA, CROATIA, AND ITALY}

\section{Summary}

In its first part, the article deals with geopolitical transformations in Istria in the light of the relations between political and ethnic boundaries. Major or minor overlapping of social and cultural boundaries in the studied area produced some extensive demographic movements or changes in the ethnic structure of Istria, as well as its internal and external spatial relations.

The article then presents some of the results of a recent investigation in the three-border area between Slovenia, Italy and Croatia in Istria. Field work and questionnaires distributed among more than 750 families in about 50 selected 
micro-areas along the Italo-Slovene and Croato-Slovene border as well as in internal parts of the Istrian peninsula in Slovenia and Croatia according to the methodology that the author of the survey has developed both on a national and international level, have shown similarities and disparities in terms of quality, intensity and orientation of cross-border relations in the investigated border region. In relation to spatial mobility of border population, the research found that the percentage of families with members that immigrated from other places is much higher on the Italo-Slovene (60\%) than on the Croato-Slovene border (35\%). On the contrary, emigration has interested $85 \%$ of families on the Croato-Slovene border and the Slovene side of the Italo-Slovene border, but only $50 \%$ of families in its Italian counterpart. People from the studied area move mostly to Trieste (17\%), Koper (11\%) and other Italian towns outside the Region Friuli-Venezia Giulia (10\%). Other most cited places are North America, Ljubljana, Izola, Australia and Rijeka (all about 5 \%). Local oriented domestic and international movements represent about $70 \%$ of total movements in the Slovenian border areas, about $60 \%$ in the Italian border area, and about $30 \%$ in the Croatian border area.

A result of this movements are cross-border kinship relations, which interest in average more than $75 \%$ of the families involved in the research. These relations are more intense in the Slovene border area with Italy and the Croatian border area (85\%), and less intense in the internal part of the Slovenian Istria and in the Italian border area (from $65 \%$ to $70 \%$ ). Considering the spatial distribution of the relatives living in the neighbouring border area, we find that $65 \%$ of the families have direct cross-border kinship on both sides of the Italo-Slovene border, whilst the same occured to 40-45\% families at the Croato-Slovene border. Social cross-border ties can be further detected considering the percentage of the respondents having friends across the border. This figure is also very significant: as much as $75 \%$ to $80 \%$ of the respondents, in fact, gave a positive answer to this question. Social ties seems to be less intense only on the Slovenian side of the Croato-Slovene border, where only half of the respondents indicated to have friends in the neighbouring country.

Actual cross-border relations are shown most evidently by intensity of and motivations for cross-border movements. As the first indicator, the majority of the people living in the investigated sthree-border " area can be equally divided into two groups: the first uses to travel across the border once per month 
or some times per year (43\% of the responses), the second visits the neighbouring countries more frequently (43\% of the responses). In the Slovenian border area with Italy as much as $25 \%$ to $30 \%$ of the respondents travel to the neighbouring country some times per week to every day. Two thirds of the respondents in Slovenia travel to Italy mostly during the week, whilst the same number of respondents in Italy use to go to Slovenia on weekends. Respondents in Croatia use to go to both Italy and Slovenia on working days (55\%) as well as on holidays (45\%), whilst respondents in Italy and Slovenia go to Croatia nearly exclusively on week-end and holidays (75\% to $85 \%$ ).

Slovenians visit Italy mainly to shop (53\% of the motives listed), visit relatives and friends $(26 \%)$ and work (11\%), whilst they go to Croatia mainly for outing (43\%) and visiting relatives and friends (40\%). Residents in Italy when visiting Slovenia usually combine leisure (31\%) with purchase of petrol $(30 \%)$; these two motivations are followed by motivations related to visiting relatives and friends $(15 \%)$, eating in restaurants $(10 \%)$ and others. Motivations for travelling in Croatia are almost totally related to leisure (75 \%), the rest depends on visiting relatives and friends (11\%) and having meals in restaurants (11\%). Finally, respondents in Croatia visit both Italy and Slovenia for the same reasons: to shop (50-52 \%), visit relatives and friends (27-34 \%), leisure $(7-10 \%)$ and work purposes (5-6\%); instead, petrol purchase is done only in Slovenia, but does not represent a major motivation (5\%).

Finally, the article move to a comparison between the Istrian »three-border" area and the previously studied Gorizia border region. The first seems to be much more dynamic in terms of demography, but it is also charcterised by greater transit flows in terms of cross-border communication and does not reach the intensity of local cross-border contacts, which is typical for the Gorizia border region. Another difference concerns the fact that in the Istrian border region functional motivations for cross-border contacts are more evident than motivations regarding social-cultural contacts. Also, cross-border contacts in Istria interest a wider space than in the Gorizia border region, where they are limited only to the border zone. From this point of view the Istrian border region is more complex, involving three bordering countries and creating thus in the Upper Adriatic a special European contact and border area. 